\title{
TRYPANOSOMA (HERPETOSOMA) RANGELI TEJERA, 1920: INFLUENCE OF HOST WEIGHT, SIZE OF INOCULUM, AND ROUTE OF INFECTION UPON EXPERIMENTAL PARASITEMIA.
}

\author{
Felix Tejero, Natiela Galli and Servio Urdaneta-Morales
}

\begin{abstract}
To study the influence of host age, inoculum size, and route of infection on Trypanosoma (Herpetosoma) rangeli, 12 lots of $6.0 \mathrm{~g}$ albino mice (NMRI strain) were infected i.p. with from $25 \times 10^{1}$ to $25 \times 10^{6}$ trypomastigotes/gram body weight harvested from LIT medium. The lower inocula produced low but persistent parasitemias, while the higher inocula produced high levels of parasitemia that fell quickly, suggesting the mobilization of resistance mechanisms. In other experiments, i.p. inoculation produced higher parasitemias than s.c. inoculation, and $6.0 \mathrm{~g}$ mice had higher parasitemias than 16.0 or $26.0 \mathrm{~g}$ mice. Thus, a standard methodology would seem to be necessary in the study of the various strains and/or species that may make up the T. rangeli complex.
\end{abstract}

Key-words: Trypanosoma (Herpetosoma) rangeli. Inoculum size. Infection route. Host weight. Immune resistance.

The study of experimental infections of Trypanosoma (Herpetosoma) rangeli Tejera, 1920 in animal models has been hampered by the low virulence of the parasite ${ }^{6}$ and the lack of precisely defined experimental conditions. In a former paper ${ }^{21}$ we have described a mouse model for obtaining high and persistent parasitemias of $T$. rangeli. The present paper describes experiments with mice of differing weights, varying numbers of inoculated parasites, and with different routes of inoculation, in order to evaluate the influence of variables such as these upon the course of infection and to determine the optimum methodology for this mouse model.

\section{MATERIALS AND METHODS}

The strain of Trypanosoma rangeli employed and the details of its culture have been described in the previous paper 21 .

In the first experiment, 12 lots of eight male white mice each (NMRI strain) weighing $6.0 \mathrm{~g}$ av. were inoculated i.p. with the following numbers of culture-derived metacyclic trypanosomes/g body wight: $25,2.5 \times 10^{2}, 5 \times 10^{2}, 25 \times 10^{2}, 50 \times 10^{2}, 1 \times 10^{4}$, $2.5 \times 10^{4}, 5 \times 10^{4}, 1 \times 10^{5}, 2.5 \times 10^{5}, 1 \times 10^{6}$, and $2.5 \times 10^{6}$.

This work was supported by the Consejo de Desarrollo Cientifico y Humanistico de la Universidad Central de Venezuela (Project No. C-03.25/85).

Instituto de Zoologia Tropical, Facultad de Ciencias, Universidad Central de Venezuela.

Address: Apartado 47332, Caracas 1041-A, VENEZUELA

Recebido para publicação em $3 / 11 / 86$
Twenty-four hours post-infection and daily thereafter, half the animals in each group were examined according to the method of Brener ${ }^{3}$ to evaluate the intensity and persistence of the parasitemia.

As explained in the results, an inoculum of 100 000 metacyclic trypanosomes/g body weight produced parasitemias that were most adaptable to experimental purposes. Therefore, in the second experiment, two lots of eight male 6.0 gram white mice were inoculated with 100000 parasites/g body weight, one group intraperitoneally and the other subcutaneously. Parasitemias were followed as above.

On finding that i.p. inoculation produced the highest parasitemias (see Results), three lots of eight male white mice, weighing $6.0,16.0$ and $26.0 \mathrm{~g}$ respectively, were inoculated i.p. with $1 \times 10^{5}$ metacyclic trypanosomes/gram body weight. Parasitemias were followed as above.

\section{RESULTS}

The results obtained are shown in Figs. 1a, b, c; 2 , and 3. All inocula, excepting the smallest $(25 / \mathrm{g})$, produced parasitemias that were patent on the first examination ( $24 \mathrm{hr}$ p.i.).

Concerning the size of the inoculum, Figs. $1 \mathrm{a}, \mathrm{b}$, and $c$ show that the larger inocula produced a higher level of parasitemia, but the smaller inocula produced a more persistent parasitemia. All parasitemias, whatever the size of the inoculum, reached their peaks between the second and fourth day after injection a characteristic of $T$. rangeli. Although the larger inocula produced higher parasitemias in all cases, there 
Tejero F, Galli N, Urdaneta-Morales $S$. Trypanosoma (Herpetosoma) rangeli Tejera 1920: influence of host weight, size of incolum, and route of infection upon experimental parasitemia. Revista da Sociedade Brasileira de Medicina Tropical 21: 135-138, Jul-Set, 1988

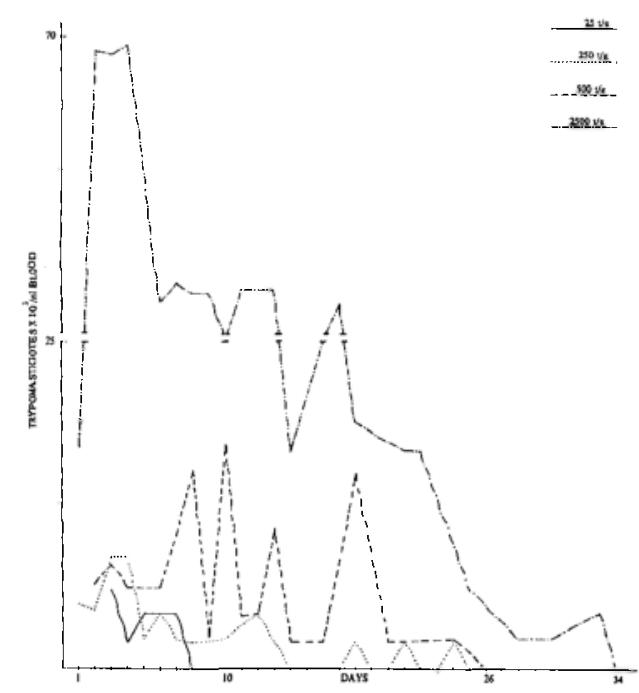

Fig. 1 - Course of parasitemia in $6.0 \mathrm{~g}$ albino mice inoculated i.p. with metaciclic trypamastigotes of T. rangeli.

a) Inocula of $0.25,2.5,5.0$, and $25 \times 10^{2}$ trypomastigotes/g body weight.

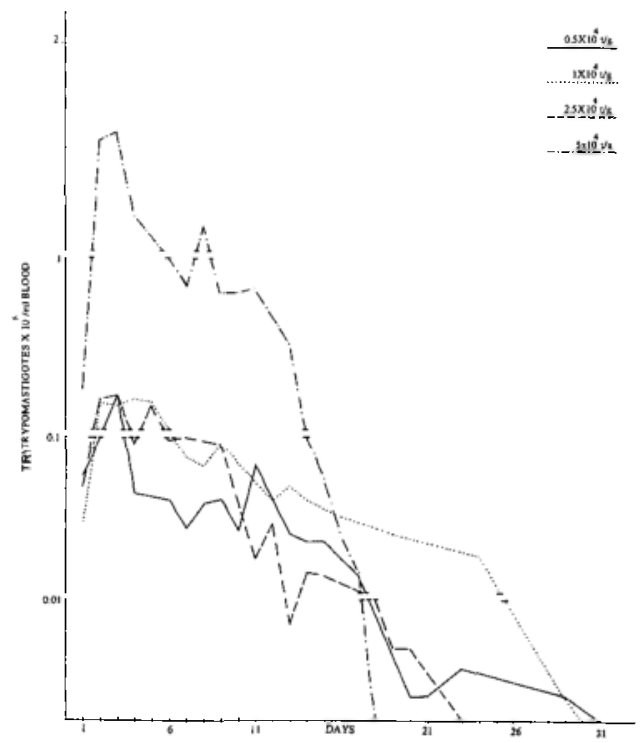

b) Inocula of $5,10,25$, and $50 \times 10^{3}$ trypo mastigotes/g body weight.

was no correlation between the size of the inoculum and the parasitemia level; rather there appeared to be a

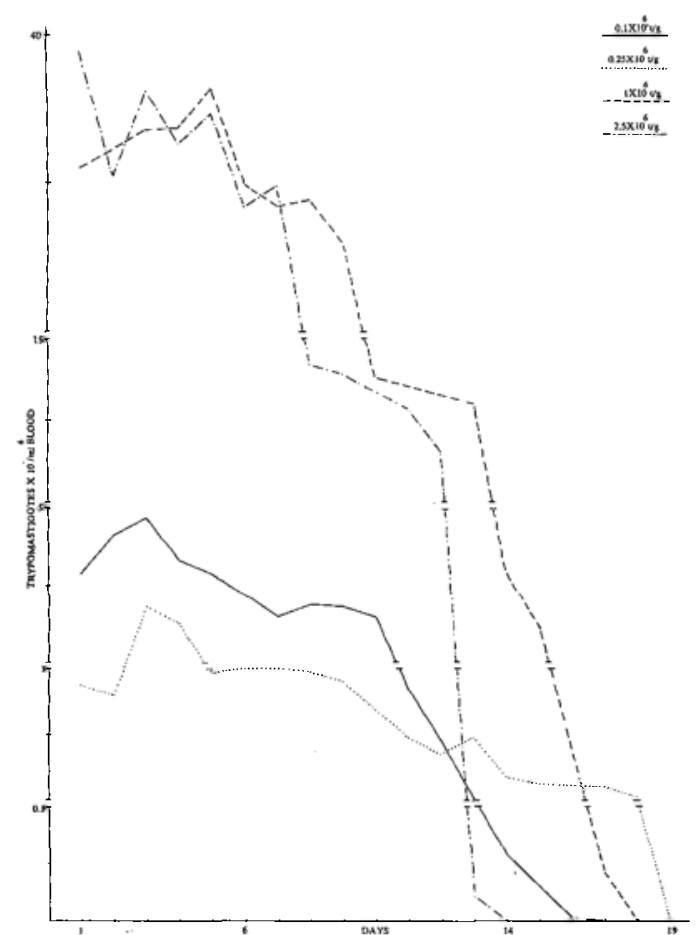

c) Inocula of $1,2.5,10$, and $25 \times 10^{5}$ trypomastigotes $/ g$ body weight.

stepwise effect, with wide ranges of inoculum size producing similar levels of parasitemia. The inoculum of $1 \mathbf{x}$ $10^{5}$ metacyclics/g produced a peak of parasitemia estimated to be 7.9 times the original inoculum, and the parasitemia persisted for 17 days, so that this inoculum appears to be particularly suited for experimental purposes.

Fig. 2 shows that i.p. inoculation of $1 \times 10^{5}$ trypomastigotes $\mathrm{g}$ produced parasitemias far higher and more persistent in $6.0 \mathrm{~g}$ mice than in 16.0 or $26.0 \mathrm{~g}$ mice.

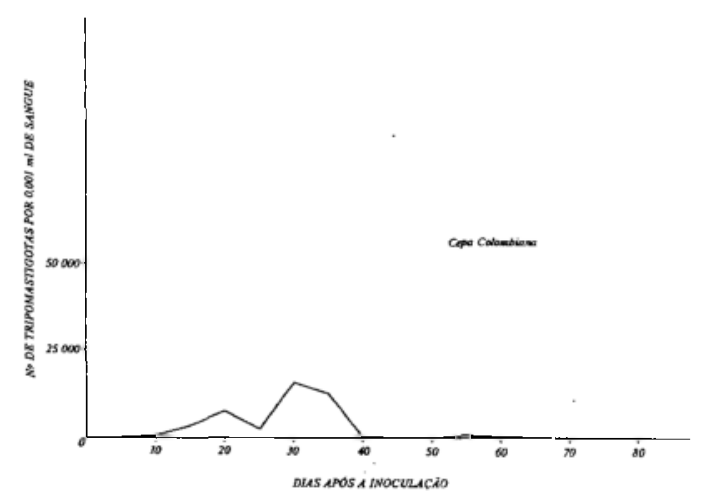

Fig. 2 - Course of parasitemia in albino mice of 6.0, 16.0, and 26.0 g inoculated i.p. with $1 \times 10^{5}$ metacyclic trypomastigotes of $\mathrm{T}$. rangeli/g body weight. 
Tejero F, Galli $N$, Urdaneta-Morales $S$. Trypanosoma (Herpetosoma) rangeli Tejera 1920: influence of host weight, size of incolum, and route of infection upon experimental parasitemia. Revista da Sociedade Brasileira de Medicina Tropical 21 : 135-138, Jul-Set, 1988

Fig. 3 shows that i.p. inoculation produced much higher parasitemias than s.c. inoculation.

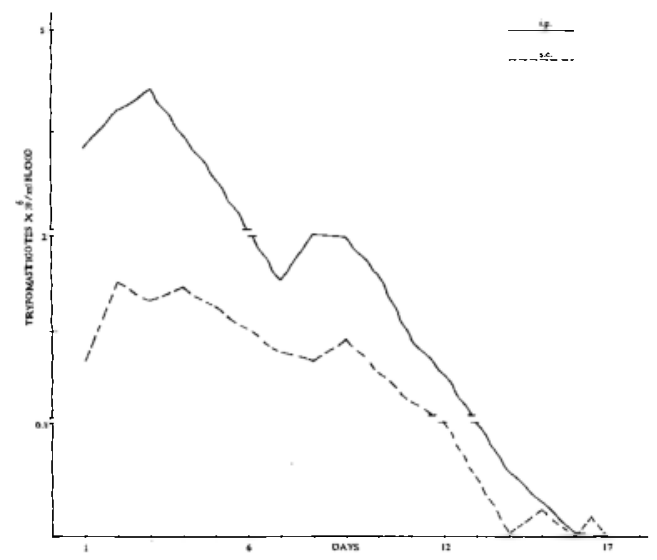

Fig. 3 - Course of parasitemia in 6.0 g albino mice inoculated with $1 \times 10^{5}$ metacyclic trypomastigotes of $\mathrm{T}$. rangeli/g body weight by i.p. inoculation and by s.c. inoculation.

\section{DISCUSSION}

In general, the published literature on experimental infections of $T$. rangeli in the mammal host has little to say on the factors which influence the course of the parasitemia, such as host age, size of inoculum, or source of inoculated parasites (blood, culture, or vector-derived). If these factors were to be standardized, it would be possible to establish the particular characteristics of a given strain of the parasite. McHardy ${ }^{13}$ has studied the influence of host sex on resistance to $T$. cruzi. Hanson ${ }^{8}$ has demonstrated differences of susceptibility to $T$. cruzi in different strains of host mice. The influence of host age $^{25}$; size of inoculum ${ }^{4} 1119$; route of inoculation 12 and source of infecting parasites ${ }^{16}$ have been determined in a variety of Trypanosoma spp.

Phillips ${ }^{17}$ emphasizes the importance of determining the inoculum which induces the greatest virulence of the parasite; the inoculation of an insufficient number of parasites may explain the attenuation or failure of infections by $T$. rangeli 7918 and by other Herpetosoma 71015 . This may also explain the failure to invade tissues of those species which have intracellular multiplication ${ }^{10,15}$.

In the mouse model which we have been developing for $T$. rangeli, we have inoculated trypomastigotes from culture, since these forms, and those produced in the vectors of the Herpetosoma, are more infective than the bloodstream forms, the former being those transmitted in natural infections ${ }^{15}$. We must emphasize the importance of using recently isolated strains of the parasite, rather than strains which have been long in culture, since long-cultured strains may have few or no metatrypomastigotes ${ }^{21}$. Attempts at infecting mice in our laboratory, using the identical regimen described above, with two strains of $T$. rangeli, one maintained in vitro for 30 years and the other for four years, have been uniformly unsuccessful (unpublished observations).

Our results indicate the convenience of using low numbers $\left(0.25-5 \times 10^{3}\right.$ metacyclics $\left./ \mathrm{g}\right)$ for obtaining long-lasting parasitemias. High levels of blood parasites persisting for an appreciable time may be obtained with an inoculum of $1 \times 10^{5}$ metatrypomastigotes/g body weight i.p. into $6.0 \mathrm{~g}$ mice. This inoculum multiplies itself nearly eight times in the mouse. While larger doses multiply to 1.6-6 times the original inoculum.

The inverse relationship between peak level and persistence of the parasitemia, plus the tendency of the parasitemias produced by inocula varying greatly in magnitude to fall into rather well-defined groups may indicate the successive mobilization of different mechanisms of resistance to the parasite, or mobilization of the same mechanisms at different levels of activity.

It has been suggested that $T$. rangeli is a complex of different strains or species 61020 . To investigate this possible heterogeneity, comparative studies would be needed on mammal hosts with flagellates from a variety of mammalian reservoirs and insect vectors. The behavior of the organisms, studied under specific conditions. Should be predictable, with the aim of stabilizing the parasite. A standardized methodology is vital to such a study.

\section{RESUMEN}

Para estudiar la influencia de la edad del hospedador. del tamaño del inóculo y su ruta de administración sobre la infección por Trypanosoma (Herpetosoma) rangeli, fueron inoculados i.p. 12 lotes de ratones albinos (cepa NMRI) de $6.0 \mathrm{~g}$ de peso con $25.0-2.5 \times 10^{6}$ metatripomastigotes $/ g$ obtenidos del medio LIT. Los inóculos mas bajos produjeron parasitemias bajas pero persistentes; los inóculos mas elevados originaron niveles altos de parasitemias que cayeron prontamente, sugiriendo la mobilización de mecanismos de resistencia a níveles diferentes de actividad. En otros experimentos, la inoculación i.p. y el uso de ratones de $6.0 \mathrm{~g}$ dieron parasitemias mas elevadas que cuando se usaron inoculaciones s.c. o animales de 16.0 y $26.0 \mathrm{~g}$. Estos resultados indican la necesidad de emplear una metodología uniforme cuando se investigue el posible carácter heterogénico del complejo de $\mathrm{T}$. rangeli. 
Tejero F, Galli N. Urdaneta-Morales S. Trypanosoma (Herpetosoma) rangeli Tejera 1920: influence of host weight size of incolum, and route of infection upon experimental parasitemia. Revista da Sociedade Brasileira de Medicina Tropical 21: 135-138, Jul-Set, 1988

\section{ACKNOWLEDGEMENTS}

The authors wist to thank Mr. Ian McLure for technical assistance and the English translation, and Mrs. Nuria Tejero for preparing the graphs.

\section{REFERENCES}

1. Añez N. Studies on Trypanosoma rangeli Tejera, 1920. I. Deposition, migration, and growth of $T$. rangeli in two mammals. Parasitiological Topics, Special Publication No. 1, Society of Protozoologists, p. 19-25, 1981.

2. Ashcroft MT. The relative virulence of Trypanosoma brucei to young and to adult white rats. Annals of Tropical Medicine and Parasitology 53: 89-92, 1959.

3. Brener $Z$. Contribuição ao estudo da terapêutica experimental da doença de Chagas. Tese. Instituto Nacional de Endemias Rurais, Belo Horizonte, Brasil, 1961.

4. Corson JF. Influence of dose of trypanosomes and of body weight in experimental infections of white rats with Trypanosoma rhodesiense. Annals of Tropical Medicine and Parasitology 28: 525-534, 1934.

5. Culbertson JT, Kessler WR. Age resistance of mice to Trypanosoma cruzi. Journal of Parasitology 28: 155$158,1942$.

6. D'Alessandro A. Biology of Trypanosoma rangeli Tejera, 1920. In: Lumsden WHR, Evans DA (ed.) Biology of the Kinetoplastida, Vol. 1, Academic Press, New York, p. 328-393, 1976.

7. Grewal MS. The life cycle of the British rabbit trypanosome Trypanosoma nabiasi Railliet, 1895. Parasitology 47: 100-118, 1957.

8. Hanson WL. Immune response and mechanisms of resistance in Trypanosoma cruzi. In: Chagas' Disease. Pan-American Health Organization Scientific Publication 347, p. 22-34, 1977.

9. Herbig-Sandreuter A. Further studies on Trypanosoma rangeli Tejera, 1920. Acta Tropica 14: 193-207, 1957.

10. Hoare CA. The Trypanosomes of mammals. Blackwell Scientific Publications. Oxford, 1972.
11. Marsden PD. Trypanosoma cruzi infections in CFI mice. I. Mortality with different doses of trypansomes. Annals of Tropical Medicine and Parasitology 61: 57$61,1967$.

12. Marsden PD. Trypanosoma cruzi infections in CFI mice. II. Infections induced by different routes. Annals of Tropical Medicine and Parasitology 61: 62-67, 1967.

13. McHardy N. Effect of sex of mice in relation to their response to immunization with vaccines prepared from Trypanosoma cruzi. Transactions of the Royal Society of Tropical Medicine and Hygiene 72: 201-202, 1978.

14. Molyneux DH. The morphology and life-history of Trypanosoma (Herpetosoma) microti of the field-vole Microtus agrestis. Annals of Tropical Medicine and Parasitology 63: 229-244, 1969.

15. Molyneux DH. Developmental patterns in trypanosomes of the subgenus Herpetosoma. Annales de la Societe Beige de Medicine Tropicale 50: 229-237, 1970.

16. Mshelbwala AS, Ormerod WE. Measurements of the infectivity of Trypanosoma cruzi in faeces of Rhodnius by comparison of dose-response curves. Journal of General Microbiology 75: 339-350, 1973.

17. Phillips NR. Experimental studies on the quantitative transmission of Trypanosoma cruzi: Considerations regarding the standardization of material. Annals of Tropical Medicine and Parasitology 54: 60-70, 1960.

18. Pifano $F$. El estado actual de la tripanosomiasis rangeli en Venezuela. Archivos Venezolanos de Medicina Tropical y Parasitologia Medica 5: 185-192, 1973.

19. Silva LH, Nussenzweig V. Sobre uma cepa de Trypanosoma cruzi altamente virulenta para o camundongo branco. Folia Clinica et Biologica 20: 191-207, 1953.

20. Tobie EJ. Experimental transmission and biological comparison of strains of Trypanosoma rangeli. Experimental Parasitology 11: 1-9, 1961.

21. Urdaneta-Morales S, Tejero F. Trypanosoma (Herpetosoma) rangeli Tejera, 1920: Mouse model for high, sustained parasitemia. Journal of Parasitology 71: 409414, 1985. 